AUSTRALIAN JOURNAL OF BASIC AND
ASSN:1991-8178
EISSN: $2309-8414$
DOI: $10.22587 /$ ajbas.2017.11.13.10
Journal home page: www.ajbasweb.com

\title{
Development of Agrotourism to Support Community-Based Tourism toward Sustainable Agriculture
}

\author{
${ }^{1}$ I Ketut Sumantra, ${ }^{2}$ Anik Yuesti, ${ }^{3}$ AA. Ketut Sudiana \\ ${ }^{I}$ Department of Agrotechnology, Faculty of Agriculture,Mahasaraswati Denpasar University, Bali-Indonesia. \\ ${ }^{2}$ Study ProgramMagister Management, Postgraduate, Mahasaraswati Denpasar University, Bali-Indonesia. \\ ${ }^{3}$ Study Program Magister Regional Planning and Environmental Management, Postgraduate, Mahasaraswati Denpasar University, Bali- \\ Indonesia.
}

\section{Address For Correspondence: \\ Department of Agrotechnology, Mahasaraswati Denpasar University, Bali-Indonesia, \\ Phone and fax 62 (0361227019); E-mail: ketut.sumantra61@ gmail.com}

\section{A R T I CLE IN F O}

\section{Article history:}

Received 19 August 2017

Accepted 1 November 2017

Available online 11 November 2017

Keywords: agritourism, development, sustainable agriculture

\begin{abstract}
A B S T R A C T
Sibetan village, Karangasem is a center of Salak (Salacca) plant in Bali and considered the origin of Salak plant. In this area was found 13 cultivars, on the other hands the visitor in agro-tourism salak is very low at $0.008 \%$ of the total of 462,233 tourists visiting Karangasem regency. This study aims to :1) identify the biophysical aspects of agrotourism, (2) study the characteristic patterns of the local institutional to support agrotourism based on community, and (3) formulating development models of agrotourism to support community-based tourism. Respondents were farmers, processors, traders and related agencies as 50 people. Data collection with interviews and FGD. Data were analyzed by using scoring techniques and swot analysis. The result showed that 1) SibetanVillage could potentially be developed as agrotourism with superior object salak garden, processed products made from plants and salacca fruits, unique culture and beautiful scenery in the hills Pemukuran. 2) Society was very interested in developing agrotourism-based community. 3) People really needed assistance both in the field of planning, development and management and assistance in post-harvest processing. 4) Needed to restructure the biophysical, social aspects, cultural, institutional, funding from government and other sources, marketing and increased a network of cooperation.
\end{abstract}

\section{INTRODUCTION}

Since Tourism is as one of the largest economic sectors and has the fastest growth, there is an assumption that this sector became the main driver of economic growth in the world (Goodwin and Chaudhary, 2017). Many developing countries glance the tourism sector as a booster of national economic performance including Indonesia. Bali is a part of Indonesia, has the largest contribution to the success of Indonesian tourism. From the GRDP of Bali amounted to 73,478.16 billion rupiahs, the contribution of trade, hotel and restaurant sector was $30.62 \%$ (Bali In Figures. 2011). However, the economic benefits derived from the tourism sector are still often accompanied by environmental damage, diversion of land functions, exploitation of social culture and crime (Bali Tourism Service, 2009; Dharma Putra, 2010). The gap between the tourism industry with agriculture in Bali is also based on the imbalance of revenue sharing agricultural use for the purposes of tourism (Astiti, 2011), so Balinese were reluctant to develop the agricultural sector.

Various studies have been conducted to obtain various policy input materials and how to harmonize the development of tourism sector with the sustainability of natural resources. Sustainability principles refer to the environmental, economic and socio-cultural aspects of tourism development, and a balancing must beestablished between these three pillars to achieved long-term sustainability (Latip et al. 2015). Based on this, it is necessary for the tourism sector to reduce the risk of natural damage and cultural exploitation of the people.

Open Access Journal

\section{Published BY AENSI Publication}

(C) 2017 AENSI Publisher All rights reserved

This work is licensed under the Creative Commons Attribution International License (CC BY).

http://creativecommons.org/licenses/by/4.0/

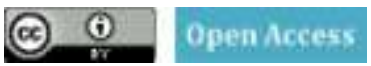

To Cite This Article: I Ketut Sumantra, Anik Yuesti, AA. Ketut Sudiana., Development of Agrotourism to Support Community-Based Tourism toward Sustainable Agriculture. Aust. J. Basic \& Appl. Sci., 11(13): 93-99, 2017 
There are three important factors that must be accommodated in the development of sustainable tourism industry is the maintenance of ecology, relationships with local communities and the satisfaction of tourists (Lesley Frace, 1997). The objective of sustainable tourism is to minimize the negative impacts of tourism development (Latif et al., 2015). Sustainable tourism refer to the development guidelines and practices are applicable to all forms of tourism in all types of destinations including mass tourism and the various niche tourism segments. Sustainabletourism also makes optimal use of environmental resources and ensures viable and long-term economicoperations by fairly distributing socio-economic benefits to all stakeholders, especially for local communitiesand and at the same time, a level of tourist satisfaction is maintained (WTO, 2004). To harmonize these three important factors, especially in countries with an agrarian cultural climate, an appropriate tourism sector is an eco-tourism based agro-tourism. Agrotourism development is facing several problems including land use change, land degradation, price fluctuation of agricultural product, and unbalanced development between rural and urban community and will increase the welfare of society (Budiarti and Listyanti, 2015). Agro-tourism is a catalyst for economic growth and income supplement (Das and Rainey, 2010) and increase revenue, promote the optimization and upgrading of industrial structure countryside (Wang et al., 2012). Agrotourism activities are diversified or consumption of natural resources and the local culture as well as the development of personal relationships between visitors and the local community ( Lathiras et al., 2010), but it can improve the quality of life by creating jobs, as well as the impact on aspects social and economic, as well as the multifunctional development of rural sustainable development (Wyporska and Mosiej, 2010; Sosnowski and Ciepiela, 2011).

There are several agro-tourism areas in Bali, one of them is SalakAgro Tourism in Sibetan Village, Karangasem Regency. The main problem in the development of agrotourism in the Sibetan Village is the number of tourist visits to agro object is very low at $0.008 \%$ of the total of 462233 tourists visiting 12 tourist attraction scattered in Karangasem (Tourism Office Prop. Bali, 2012). The causes of travelers is difficult to get the fruit to be plucked directly, especially outside the main harvest from December to March (Sumantra et al., 2012;Sumantra et al, 2014). There are no any collection gardens and objects of agrotourism are not managed properly from the area made the object of the arrangement, the operational activities of the tour, human resources and marketing. This reason requires exploration activities to obtain data support in the form of factors considered to be the strategy of developing the object of agro-tourism (Sumantra et al., 2015)

This study aims to 1) identify the biophysical aspects, (2) study the characteristic patterns of local institutions to support the agro-tourism basedsociety, and (3) formulate strategy of development model agrotourism in the Sibetan Village.

\section{Research Method:}

The research was conducted by a survey method with field observations, interviews, and literature which was located in Salak Agroturism of Sibetan Village. Data were analyzed by using descriptive qualitative through the understanding of RRA (Rapid Rural Appraisal) and understanding of PRA (participatory rural appraisal), and a SWOT analysis supporting the development agrotourism. Recommended model of developing agrotourism based on the identification and analysis of potential environmental and natural resources, agricultural potential to be integrated with the analysis in terms of socio-economic, institutional and partnership in development. The focus of this research was the development model of agro-tourism with the approach of community based tourism, which includes: (a) programs to empower communities in developing agro-tourism, (b) community involvement in the planning process development of agro-tourism in the Sibetan Village, (c) infrastructure that supporting agro-tourism development, (d) the promotion of agro-tourism, and (e) encourage the growth of the partnership.

\section{Findings And Discussion:}

\section{Biophysical Condition of Salak Agro tourism in Sibetan Village:}

Sibetan Village is a village with a pattern of Life 'society of agricultural field, especially farmers of salacca. The area of salacca farming in this village were proximately 1,125,000 hectares, located in altitude 400-600 meters above sea level, with temperatures of $20-30^{\circ} \mathrm{C}$, as well as rainfall $1.567 \mathrm{~mm}-2000 \mathrm{~mm}^{-1} \mathrm{rar}^{-1}$. Clay soil texture, organic content medium, N-medium, P-very high and K-Very low, acidty pH. Based on soil map which was half detail, soiltype was typic Hapludalfs, volcanic, isohipertermik (PuslitandanAgroklimat-Bogor, 1994). Family of soil was found in Districts of Telaga, Karanganyar, Dukuh in Sibetan Village (Sumantra,et al., 2012). Sibetan Village was located in the district Bebandem, $8 \mathrm{~km}$ from Amlapura City, $20 \mathrm{~km}$ from Candidasa and 80 $\mathrm{km}$ from the city of Denpasar.

Sibetan Village had typical characteristics of its own, especially intermsof natural potential of agriculture, better known as Salak Plantation, with 13 cultivars included Salak Injin, Salak Nangka, Salak Putih, Salak Boni, Salak Penyalin, Salak Cengkeh, Salak Gondok, Salak Nenas, Salak Bingin, Salak Cemara, Salak Kelapa, Salak Gulapasir, Salak Muani, and Salak Embadan (Sumantra et al. 2015). Among the 13 cultivars, Salak Gulapasir was the most famous (Sumantra et al., 2012). And nowadays, this salak had produced another 3 new varians 
those were Salak Gulapasir Nanas, Salak Gulapasir Nangka, dan Salak Gulapasir Gondok(Sumantra and Martiningsih, 2016). These Salak were not only freshly consumed but also processed into several processed products and accompanied with some operating processed products made from salacca, including: wine, dodol, chips, syrup and candies, which made this village different from other villages in Karangasem (Sumantra, et al., 2015).

Farmers in the Sibetan Village planted the salak under shade plants. Shading plants of salacca plant were very important because these plants were not resistant against sunlight full (Sumantra et al., 2012.) Other benefits of the protecting plants was enabling to modify microclimate such as air temperature and soil (Sumantra et al,2012; . Sumantra et al., 2014), conservation of flora and fauna (Priyadarshini et al., 2011).

Results of the inventory of shading plants in the cultivation system of Salak in Sibetan were amounted to 13 kinds. Dadap plants (Erythrina variegata L) showed the highest importance value index (IVI) ie 66.52\%, then followed Banana plants (Musa paradisiaca L), with IVI 58.36\%, durian (DuriozibethinusMurr), Sengong (Albisia falcate), Coconut (Cocos nucifera), mangosteen (Garcinia mangostana L) and Gamal (Glyricidiasepium) with IVI 25.44\%, 24.93\%, 24.55\%, 22.75\% and 20.74\%, The identification results showed the diversity of protecting plants were Still low by Values Diversity Indexs (H<1) (Sumantra, et.al., 2012).

\section{The social aspectof Agro-Tourism:}

Number of families of ten Banjar were 2,186 households with a population of 8,618 inhabitants which consisted of 4,305 males and 4,313 females. Sibetan Village education level was still relatively low, seen from the number of people who mostly are in complete primary school level / equivalent as many as 811 people $(37.95 \%)$, as many as 545 people graduated from junior high school $(25.50 \%)$, and highest level of education to Bachelor (S1) as many as 305 people (14.27\%). Most of the villagers in Sibetan livelihood as farmers so that farming community institutions patterned ie farmer groups. Farmer groups to develop Salak Agro tourism that was a group of Dukuh Lestari, Mekar Sari groups and farmer groups in Karanganyar village, which is supervised by the Office of District Tourism, Agriculture department and the university. The group had already developed a range of activities in the field of tourism as well as processed products based on fruits.

Sibetan indigenous village had a tradition of such religious processions Ngusaba implementation dangsil, Ngusaba ceremony deha was a rare and unique ceremony, the stage of the deha and young men with oversized clothes was a potential supporter agrowista development. Fostering community about asset management of natural resources and agrosalakwas not maximized as well as economic institutions which had not run optimally.

\section{SWOT Analysis of SalakAgro-tourism: \\ External Factors: Strength $(S)$ :}

a) The potential for a strong and unique salak agro-tourism and the genetic diversity of salak Bali reached 13 types.

b) The desire of the community to develop agro-tourism

c) Village environmental security

d) Farmers were already capable of yielding a household product industry based fruits such as salak wine, chipsand culinary products made ponds (puppies salak).

e) It was also a plantation area of environmentally friendly, because the farmers never used chemicals.

f) A beautiful panorama in the region and the area was also close to attractions Bukit Pemukuran, tourist attraction Candi Dasa, Tirta Ganga and Pura Agung Besakih.

g) Hospitality of Sibetan villagers

Weakness (W):

a) Implementation regulations Bali Province No. 3 in 2013 have not been implemented optimally makeover

b) There is no collection garden and feared some kind will be extinct.

c) Travelers were difficult to get the fruit to be plucked directly, especially outside the harvest season (December-March).

d) The object of this agro not managed properly from the area made the object of the arrangement, the operational activities of the tour, and human resources.

e) There are adequate lodging facilities available and the path of travel is clear.

f) Promotion and marketing cooperation had not run well

g) People did not have experience in managing agrotourism as a tourist attraction and the funds for the settlement area wass not yet available 


\section{Internal Factors: \\ Opportunity $(O)$ :}

a) A visit to Bali travel from year to year showed an increasing trend.

b) Development of agrotourismwould be able to preserve and simultaneously created opportunities formation of new cultivars.

c) Economic community will be increased due to the results of domestic industry.

d) Government policy in developing ecotourism object

e) Support of production, result processing and communication technology

f) The existence of community trend towards nature tourism

g) The presence of assistance from investors

Treath (T):

a) The establishment of new agro-tourism in the area adjacent to the object of salacca agrotourism feared to disrupt the continuity.

b) The effect of the development of agrotourism often rub together when it was not prepared as mature as possible, especially the culture brought foreign tourists.

c) There was no a master plan for the development of objects by the government

d) Tourists tend to visit in the southern bali area and western bali

e) Influence of foreign culture would weaken the original culture of sibetan area

\section{Agro-tourism Development Strategy of Community based of Salak Garden:}

Strategy of Strength- Opportunity (S-O)

1. Digging and arranging the natural potency in the hill of Pemukuran, arrangement of tourism objects which include arrangement of salak garden, demonstration garden, collection garden, garden arrangement at the top view of Pemukuran Banjar Dukuh, making processed products based on Salak in Banjar Telaga. Institutional empowerment of agro-tourism supporters should be encouraged. These organizational units would play a role and perform tasks according to their function. The Women Farmer Group will provide products of the household industry that has been produced (Budiarti et al., 2013). The group directly assigned as the agrotourism Team performs their tasks from receiving guests, assisting and providing services to tourists and bali garden development and processing of post-harvest products based on Salak to optimize agro tourism object development.

\section{Community Support}

The people of Sibetan Village did not understand the concept of community-based agro-tourism. The introduction of the Agro-tourism model caused them to know and agree to develop the business because it would have a wider impact on the village economy and employment opportunities for the local community. This was realized by providing information and more in-depth feedback about the plan and hope to develop agro tourism. Development plan was poured in the form of a chart and a map of the things that need to be worked on in the recana. Besides, the community needs support in increasing the capacity of human resources which was still considered to be less especially in the ethics of receiving guests, language mastery and management. Tourism-related and agro-tourism training needs to be provided to the community, and communities need to be involved in agro-tourism development planning in their area (Hamzah et al., 2012) Sibetan villagers also needed funding sources to support agro-tourism, whether funding sources will be via BUMDes or forms of Cooperatives or other beneficial sources and ease in obtaining funding in developing the already growing household industry today. In addition, the community was in need of regulations that could regulate and also be used as a reference in the management of agro-tourism so that all the components involved in it couldbe benefit and fair.

\section{Strategy of Weakness- Opportunity (W-O):}

1. Increase promotion. Promotion was the means by which the company in an effort to inform, persuade, and remind consumers directly or indirectly about the products and brands they sell. Various forms of promotion conducted by the Department of Tourism much influenced by the needs of the department and based on the target increase in tourism commodities to increase foreign exchange State.

2. Development of facilities and infrastructure was necessary to provide services to tourists to meet their diverse needs. The arrangement and the making of parking facilities for guest vehicles, lodging, office, walkway showroom, public toilets and other facilities become important in agro-tourism development strategy based on salak garden.

\section{Strategy ofStrength-Treath (S-T):}

Establishing Partnership with stakeholders. The creation of regional autonomy, in accordance with laws and regulations, especially Law No.32 of 2004, the District Government was entitled to conduct its own policies by conducting programs in accordance with the conditions and potential of the region, namely through 
agriculture-based tourism sector. These program were, among others, by cooperating with private institutions that were fully committed to the progress of agriculture-based tourism sector, which was a partnership with agro-tourism management of SalakSibetan.

\section{Strategy ofWeakness -Treath (W-T):}

Community empowerment was a process for the community's independence in order to improve their living standards by using local resources as possible. The process of putting the public was the main part or the center of the development. Training programs that were undertaken by the Government of Karangasem regency was in the form of training and coaching to improve the ability of communities in order to utilize existing resources. In planning the agrotourism as a tourist attraction, people participate in field practice by providing learning the facts that occurred in an area such as a survey or study. Through these activities the community would be directlyaware of the problems, so that people had an idea to make a plan in accordance with local conditions.

Indicators of achievement for community empowerment Sibetan views of capabilities: (1) The public was able to access the means of production and marketing; (2) The public was able to produce a superior product that was worth the high rate so that the program became a partnership agrotechnopark educational tourism education from various regions; (3) Improving the status and self-image in their cultural identity

\section{Determination of Key Strategies With Analysis of Quantitative Strategic Planning Matrix (QSPM):}

Based on the formulation of SWOT analysis, there were several strategies that could be applied in Salak Agro-tourism of Sibetan village. QSPM analysis was known that the main strategy that needed to be done in the development of agro-tourism was to improve the infrastructure and structuring of the area, especially in the management of the collection garden with the highest total attractiveness (TAS) value, the next strategy was to optimize the benefits of the product and keep the product always available continuously (Table 1).

Table 1: Result of QSPM of Salak Agro-tourism in Sibetan Village
\begin{tabular}{|l|l|l|}
\hline No & Strategy & Total \\
\hline 1 & Improving infrastructure, structuring the area and improving agro-forest collection management system & 530,25 \\
\hline 2 & $\begin{array}{l}\text { Optimizing the benefits of Salak agro-tourism products and still keep the product quality and continue } \\
\text { to be continuously available }\end{array}$ & 515,10 \\
\hline 3 & Enhancing optimal promotion both manually and by utilizing technology & 510,80 \\
\hline 4 & Increasing the role of government to facilitate agro-tourism activities & 480,50 \\
\hline 5 & $\begin{array}{l}\text { Improving the quality of tour guide field resources and the quality of the processed product provider } \\
\text { groups through training and comparative studies. }\end{array}$ & 460,50 \\
\hline 6 & $\begin{array}{l}\text { Improving the quality of land and water resources through the effort of conservation of soil, water, } \\
\text { plants and animals }\end{array}$ & 455,47 \\
\hline 7 & $\begin{array}{l}\text { Increasing the cooperation and partnership of stakeholders for the sustainability of agriculture and } \\
\text { improve the synergy of agriculture with tourism }\end{array}$ & 430,68 \\
\hline
\end{tabular}

\section{Evaluation of Community-Based Agro-tourism Sustainability:}

Evaluation of community basedof salak agrotourism sustainability in the SibetanVillage of the physical, socio-economic and cultural aspects indicated that the physical aspect requiring corrective action and restructuring further. While the social aspects of economic and cultural aspects showed a good direction towards sustainability. Some facts in Bali showed, the development of tourism facilities were followed by the land conversion. These events should be anticipated through the specific regulations that could be written in awigawig(rules) of indigenous villages, thus increasing the value of land use were able to increase the income and standard of living. In line with the research results of other countries such as Malaysia that the development of agrotourismwere able to raise public awareness about sustainable development, improve the system of social empowerment, strengthen social bonds them and develop social skills in relation with the increase of people's income, diversification and intensification of economic activities, providing employment and poverty alleviation (Hamza et al., 2011). The development model of agro-tourism as a tourist object needs to consider a variety of factors at play, including physical factors, community and socio-cultural, economic, technological, legal and policy aspects, the level of supply and demand farm tours, experience gained by tourists when visiting the tourist area of agriculture. These factors needed to be analyzed to get the appropriate development model (Budiarti et al, 2013).In line withAbdul Latip et.al.( 2015) tourism management and process must include all stakeholders in order to achieving the sustainable tourism.

\section{Recommendation of Model of Development Agro-tourisms community-based tourism of Sibetan Village:}

1. Improving the infrastructure and structuring of the area and the management system of the garden to produce salak fruit continuously and build the garden of salak collection as supporting agro tourism 
2. The potential diversity of plant salacca, protective plant species based processed products of fruits, natural beauty and unique culture that is owned by the Sibetan Village developed for the preparation of agrotourism program.

3. Potential gardens and natural beauty synergized with the potential for processed products in the community could be offered to visitors in the agrotourism program.

4. Optimally Increasing promotion both manually and by utilizing technology

5. Increasing government participation to facilitate agro-tourism activities and assist in the provision of supporting funds.

6. Improving the sustainability of agriculture through conservation of resources (land, water, vegetation, and wildlife).

7. Increasing the cooperation and partnership of stakeholders for the sustainability of agriculture and improve the synergy of agriculture with tourism.

\section{Conclusion:}

1. Sibetan Village had the potential development of agrotourism as a tourist attraction with a leading community-based overlay salacca garden, refined products made from plants and fruits, unique culture and beautiful scenery in the Pemukuran Hill, Banjar Dukuh.

2. Community of Sibetan Village were very interested in developing agrotourism as a community-based tourism.

3. Community really needed assistance both in the field of planning, development and management of agrotourism as well in post harvest processing of fruits.

4. Need to restructure the biophysical, social aspects, cultural, institutional, government funding and from other sources, marketing and improvement of cooperation networks.

\section{ACKNOWLEDGMENTS}

Our gratitude to DRPM, DirektoratJenderal Pendidikan Tinggi, KEMENRISTEKDIKTI that has funded this Research through Hibah Penelitian MP3EI 2015-2017.

\section{REFERENCES}

Abdul Latip, N., A Marzuki, M Pimid, M Umzarulazijo Umar, 2015. Indigenous People, Conservation and Sustainable Tourism at Lower Kinabatangan,Sabah: SWOT Analysis. Australian Journal of Basic and Applied Sciences, 9(7): 331-334.

Bali In Figures, 2011. Bali Central Statistics Agency, Arysta Jaya Denpasar.

Bali Tourism Service, 2010. International Seminar on Tourism Harmonization Development, Faculty of Tourism, Udayana, Denpasar.

Bali Tourism Service, 2012. Number of tourist visits on tourist objects in Bali.

Budiarti, T and A.D. Listyanti, 2015. Development of Community-Based Agritourism on Integrated Farming System toward Sustainable Village. Australian Journal of Basic and Applied Sciences, 9(7): 242-244.

Budiarti, T., Suwarto, I. Muflikhati, 2013. Pengembangan Agrowisata Berbasis Masyarakat pada Usahatani Terpadu guna Meningkatkan Kesejahteraan Petanidan Keberlanjutan Sistem Pertanian. JurnalIlmu Pertanian Indonesia (JIPI). 18(3): 200-207.

Darmadi, AAK., A. Hartana, J.P.Mogea, 2002. Perbungaan Salak Bali. Hayati, 9(2): 59-61.

Das, B.R. and D.V. Rainey, 2010. Agritourism in the Arkansas Delta Byways: Assessing the Economic ImpactsInt. J. Tourism Res., 12: 265-280.

Dharma Putra, 2010. Pencemaran Lingkungan Ancam Pariwisata Bali,:Manikgeni.

Goodwin, R.D., Chaudhary, Suman Kalyan, 2017. Eco-Tourism Dimensions and Directions in India: an Empirical Study of Andhra Pradesh. Journal of Commerce and Management Thought; Pune8.3 (Jul/Sep 2017): 436-451.

Hamzah, A., S.M. Yassi, B.A. Samah, Jeffrey Lawrence D’Silva1, N.Tiraiyaei, H. Mohamed Shaffril and J. Uli, 2012. Socio-economic impact potential of agro tourism activities on DesaWawasan Nelayan community living in Peninsular Malaysia. African Journal of Agricultural Research, 7(32): 4581-4588.

Lathiras, P., A. Zopidou, J. Mylonakis, P. Tahinakis, N. Protogeros, and I. Valachis, 2010. An Evaluation Of Websites Quality Factors In Agro Travel And Ecotourism. Tourism and Hospitality Management, 16(1): 1130 .

Latip, N.A., A. Marzuki, M. Umzarulazijo Omar, Marcela Pimid, 2015. Sustainable Tourism's Indicator in the Protected Area: the Case of Kinabalu Park, Sabah. Australian Journal of Basic and Applied Sciences, 9(4): 95-103.

Lesly France, 1997. The Earthscan Reader in Suatainable Tourism, Earthscan Publications Ltd. 
Priyadharsini, R.K., D. Hairiah, Suprayoga, J.B. Baon, 2011. Keragaman pohon penaung pada kopi berbasis agroforestry dan pengaruhnya terhadap layanan ekosistem. Berk. Penel.Hayati edisi Khusus, 7: 81-85.

Pusat Penelitian Tanah dan Agroklimat, 1994. Peta semi detail daerah Nusa Dua - Padangbai, Skala 1: 50.000. PuslitandanAgroklimat, Bogor. Lembar, pp: 1807-41.

Sosnowski, J. and G.A. Ciepiela, 2011. Financial Result Analysis Of Agrotouristic Farms Activities In Siedlce Region. Oeconomia, 10(1): 97-108.

Sumantra, K. dan Labek Suyasdi Pura, 2012. Analisis neraca air lahan pada pertanaman salak gulapasir se bagai dasar untuk pembuahan di luar musim. Jurnal Agrimeta, 02(03): 1-12.

Sumantra, K., Sumeru Ashari, T. Wardiyati, Agus Suryanto, 2012. Diversity of shade trees and their influence on the microclimate of agro-ecosystem and fruit production of gulapasir salak(Salacca Zalacca var. Amboinensis). International Journal of Basic\& Applied Sciences IJBAS-IJENS :12(06): 214-221.

Sumantra, K., N. Sumeru Ashari, Labek Suyasdi Pura, 2014. Heat unit, phenology and fruit quality of salak (Salacca Zalacca var. Amboinensis) on different elevation in Tabanan regency Bali. J.Agriculture, Forestry and Fisheries, 3(02): 102-107 (http://www.sciencepublis hinggroup.com/j/aff)

Sumantra, K., Anik Yuesti, P. Sujana, 2015. Development of Agrotourism-Education Based on Diversity of Salak in the Sibetan Village As Germplasm Conservation Efforts. In Proceeding International Bilateral Biosecurity Summit "Secure Food Futures". pp: 109-116.

Sumantra, K. and Ni GAG EkaMartiningsih, 2016. Evaluation of the Superior Characters of Salak Gulapasir Cultivars in two Harvest Seasons at the New Development Area in Bali. International Journal of Basic\& Applied Sciences IJBAS-IJENS: 12(06): 19-22.

Wang, L., S. Cheng, Q. Min and L. He, 2012. Driving force and development strategies of agro-tourism in China. Journal of Eco-Agriculture, 20(6): 681-687.

Wyporska, K. and J. Mosiej, 2010. Technical Infrastructure For Environmental Protection At The Level Of Farms As A Factor Of Sustainable Rural Development. Journal Economic and Environmental Studies, 10(1): 71-84. 